\title{
What Is Wrong with Competency Research? Two Propositions
}

\author{
Rossilah Jamil $^{1}$ \\ ${ }^{1}$ International Business School, Universiti Teknologi Malaysia, Kuala Lumpur, Malaysia \\ Correspondence: Rossilah Jamil, International Business School, Universiti Teknologi Malaysia, Level 10, Razak \\ Tower, Universiti Teknologi Malaysia Kuala Lumpur, Jalan Sultan Yahya Petra, 54100 Kuala Lumpur, Malaysia. \\ Tel: 60-332-180-5050. E-mail: rosillah@ibs.utm.my
}

Received: July 7, 2015 Accepted: August 11, 2015 Online Published: August 28, 2015

doi:10.5539/ass.v11n26p43 URL: http://dx.doi.org/10.5539/ass.v11n26p43

\begin{abstract}
The theory and practice of competency approach has remained significant even decades after its conception. However despite its omnipresence, its validity has been repeatedly questioned. For it to be a truly useful tool, these criticisms and their roots must be critically analyzed to identify improvement measures. To find the solutions, a proper analysis of the competency subject must be first conducted. This paper aims to revisit the prevailing competency theories and backgrounds, with the intention to identify gaps and propose corrective measures. This paper starts by reviewing the theoretical foundations underpinning the competency approach, its origins, frameworks and key criticisms. Based on the reviews, it was found that the approach suffers two limitations. Firstly, its frameworks tend to be bias towards achieving utilitarian objective whereby definition of competent managers is limited to their contribution to organizational economic performance. Secondly, its research were mainly conducted from the positivistic lenses which over-simply the complex nature of managerial work. Based on these findings, the author then proposes epistemological and ideological turns that researchers should consider in researching the competency subject.
\end{abstract}

Keywords: competency, competence, criticisms, managers, epistemology, ideology, future research

\section{Introduction}

The theory and practice of competency approach has remained significant decades after its conception. A simple search using the term in the EBSCOhost database yields over 4,000 academic articles. The approach is being used across the globe for instance in Europe (Horton, 2000a; Hondeghem \& Vandermeulen, 2000), Australia (Gonczi, 1994), China (Liu et al., 2007), South Africa (Parker \& Walters, 2008), Middle East (Ismail et al., 2009) including Malaysia (Azmi, 2010; Azmanirah et al., 2014). Competency is an important tool in organizational human resource management efforts. It is not only being applied in private organizations, but also in public sector (Horton, 2000a; Hondeghem \& Vandermeulen, 2000) and non-governmental organizations (Besler \& Sezerel, 2011). This collection of evidence suggests that competency is progressive in both theoretical and practical terms.

However despite its omnipresence, validity of the approach has been repeatedly questioned. For it to be a truly useful tool, these criticisms and their roots must be critically analyzed to identify measures for improvement. Moving along this thesis, this paper aims to revisit the prevailing competency theories and backgrounds, with the intention to identify gaps and propose measures with regard to the approach taken in researching the subject. The article is organized as follows. It starts with a discussion on the theoretical underpinnings of the competency approach with a special focus on the American and British competency movements, two countries where the concept received most of its early developments. These two countries were also chosen given their standing as the classic cases in explaining the competency(e) terminology debates. The article then progresses to an analysis on several key competency definitions, its properties, samples of competency frameworks and its ideological foundations. To proceed further, its main criticisms together with an analysis of their root causes are discussed. The author then concludes the article by proposing some measures on how these criticisms could be addressed in future research in the subject.

\section{Theoretical backgrounds}

\subsection{Origins}

The origin of competency dates back to the medieval time during apprenticeship trainings (Horton, 2000b). 
Industrial revolution, scientific management, and post World War II economic booming in the United States (US) gave rise to the concept whereby interests and initiatives were taken to organize occupations with their required skills and knowledge (ibid.). Afterwards, much development in the competency approach has been reported taking place in the US and the United Kingdom (UK), both who have had significant contributions in the conceptualization and practice of the competency approach.

In the US, the development of competency can be traced to individuals in the McBer consulting firm. The concept was first proposed by Harvard psychological professor, David McClelland, who established the firm in 1963. Backed by many empirical research data, McClelland famously debunked the validity of traditional aptitude and intelligence tests like exams in predicting individuals' success in career and life (McClelland, 1973). Instead he argued that individuals are successful because of their underlying characteristics that explain their superior performance. To determine these characteristics, McCelland developed two instruments: 1) Criterion Sampling - which studies the behavioural differences between high and average performers; and 2) Behavioral Event Interviews (BEI) - highly structured interviews on successful people to extract their hidden characteristics, thought process, and feelings which explain their successful behaviors. The competency approach was then popularized, by Richard Boyatzis in his book 'The Competent Manager' (1982). In 1981 Boyatzis, then a McBer's consultant, was commissioned by the American Management Association to develop a generic model of managerial competency based on McBer's existing projects. The result was a generic managerial competency model based on an intensive, large-scale empirical research involving 2,000 managers holding 41 different jobs in 12 organizations. Due to this, Boyatzis was recognized as the person who first formally defined the word competency (Note 1). Many of subsequent studies on competency in the US generally emanated from the works of McBer, for instance Spencer and Spencer (1993) who were also researchers in the company.

Comparatively, the emergence of competency in the UK took a very different route. The 'competence movement' in the UK is a controversial government-initiated political agenda (Thorpe \& Easterby-Smith, 1997). It was introduced to enhance the effectiveness of the British workforce with the formulation of the National Vocational Qualification (NVQ) who was responsible in developing the standards of various occupational groups. The competency influence made way into management education setting due to simultaneous publications by Handy et al. (1987) and Constable \& McCormick (1987) whose reports associated British's poor international economic performance to the country's lack of attention and formality in managerial education and development. The reports set forth the professionalization of management in the UK with the formation of the Management Charter Initiative (MCI) in 1987 followed by the Management Standards Center (MSC) in 2000. The objective of the MCI is to develop standards for managerial jobs and to award accreditation to 'qualified' managers. Further discussions on the divergence and convergence of the competency movements in both countries can be referred in Horton (2000b). Unlike the US approach which looks at individuals' traits, the UK competence approach focused on functional analysis method which involves seeking opinions from industry experts to determine functions of a particular job and the minimum level its incumbent has to perform. Therefore, the competence approach does not really differentiate or seeks to determine what makes people exceptional in their job performance which is the focus of the American technique.

These conceptual backgrounds result double-barrel terminologies in the competency/e literatures. Competency in the US was referred as the 'behavioural approach' and defined as individual attributes that are related to effective performance. Whereas, in the UK the term 'competence' is more common that reflects an achievement of occupational standards. Competency was referred as an independent variable whilst competence as a dependent variable (Grzeda, 2005). The US approach was called 'input approach' in comparison to the UK's 'output approach' (Hoffmann, 1999). The competence approach is more acceptable for tangible jobs but less suited for complex jobs like management (ibid.). Some English writers used 'meta competence' to refer to the US approach (eg. Brown, 1993). The two terms do overlap in some areas. Competencies are necessary for competent performance and vice versa (Woodruffe, 1993; Young, 2002; Mumford \& Gold, 2004), although this relationship is not necessarily causal. Having the right competencies is only one of the important ingredients for effective performance (Boyatzis, 1982; Woodruffe, 1993). There is also measurability connotation in most US-based competency definitions (for eg. Spencer \& Spencer's, 1993) which implies a comparison to a standard, thus making the US approach similar to the UK approach. For the purpose of this writing, the term competency is used as it is believed covers the properties of both US and UK definitions.

\subsection{Ideologies}

Table 1 shows some samples of managerial competency frameworks based on literature reviews or empirical research. In general most frameworks, especially the traditional ones, have overlooked the need for ethical 
competency (Jamil, 2011). This may be due to the definition of effectiveness was based on the success of managers in achieving organizational profit objectives. Competencies regarded as contributors / necessary for effective performance are those that have direct use to organization profit maximization agenda. As such, the frameworks suggest that organization is regarded as the main, if not the sole, stakeholder. The limited attention paid on ethical competency in managerial frameworks has also been noted by Burgoyne (1989) and Cheetham and Chivers (1996).

Table 1. Selected examples of competency frameworks

\begin{tabular}{ll}
\hline \multicolumn{1}{c}{ Authors } & \multicolumn{1}{c}{ Competency frameworks } \\
\hline Boyatzis (1982) & Goal and Action Management, Leadership, HRM, Directing Subordinates, \\
& Focus On Others, Specialized Knowledge \\
Viitala (2005) & Interpersonal Competencies, Social Competencies, Leadership and \\
& Supervisory Competencies, Knowledge Management Competencies, \\
& Business Competencies, Technical Competencies. \\
Su-Chin et al (2012) & Communication Skills, Teamwork, Ability to Learn, Implementation, \\
& Problem Solving, Self-control, Initiative, Enthusiasm, Customer-service \\
& Orientation, Relationship Building, Time Management, Leadership. \\
\hline
\end{tabular}

The competency approach is conceptualized based on two main ideologies: social efficiency theory and developmental humanism (Garavan \& McGuire, 2001; Hyland, 1994). Bias towards organizational effectiveness in many traditional competency frameworks is due to the dominance of social efficiency ideology in competency studies. The key and most common thrust is based on Taylor's social efficiency theory which supports utilitarian objectives. This principle is prevalent in competency frameworks developed in the disciplines of management, human resource, and to a certain extent, psychological (e.g. Prahalad \& Hamel, 1990; Clardy, 2008; Boyatzis, 1982). Developmental humanism which pursues educational objectives is the less common perspective in competency studies. Frameworks founded by this perspective are more prevalent in education. Approaching competency from the social efficiency perspective seems in keeping in the context of workplace learning as profit maximization tends to be the dominant principle that governs business decisions.

Much of the literature claims that competency is not only concerned with economic objectives but can also be compatible with broader, educational missions. Its advocates (like Hager \& Beckett, 1995; Albanese, 1989; Hyland, 1996) argue that the approach can develop whole individuals and can thus be appropriately applied in formal education. This perspective is especially applicable in the context of practical-oriented education like the Master of Business Administration (MBA) programs where development of holistic managers is crucial (Rees et al, 2015) Speaking from the context of workplace learning, Finch-Lees et al. (2005) also defended the approach stating that it could actually liberate and empower individuals, which is therefore in line with the concerns of critical theorists. Given the multi-faceted interpretations by its stakeholders, Hoffmann (1999) argues that the aim should not be in finding a single true definition that can satisfy everybody, but to select one which suits an intended purpose and context.

\section{Criticisms}

Despite its significance the competency approach is plagued with long-standing controversies. The main criticism is on its over-simplification of the complex nature of managerial roles. Its view and quest for the 'ideal' model of effective management behaviours suggest that managerial jobs are universal and standardized. Such thinking reflects the theory of scientific management which has become increasingly irrelevant in today's world. The manner in which the competency approach tries to capture all the mysteries of managerial work into sets of 'to do' and 'to have' lists has been considered an insult to managerial communities (Antonacopoulou \& FitzGerald, 1996). It has been argued that competencies have failed to provide enough subtleties, complexities and contextualities necessary for effective leadership in organizations but have produced conformity and unfocused leadership model (Bolden \& Gosling, 2006).

Secondly, the approach is also criticized for assuming that competencies and effective performance is necessarily direct, observable and testable relationships. This criticism is targeted more towards the British MCI competence framework which is concerned with the measurement of managerial performance outputs to some predetermined standards with the purpose of accrediting the performance according to several competence levels. Such practice 
ignores the fact that effective managerial performance most of the time involves intangible and hard-to-measure elements. By focusing on the output, the MCI method failed to recognize that there are various ways to which managers learned and became competent (Burgoyne, 1989). In other words, adoption of the MCI framework across Britain suggests there is only one way for managers to become competent, and that is through the MCI accreditation. Antonacopoulou and FitzGerald (1996) also noted the same stating that the system disregards the significance of the managerial learning process.

Thirdly, the lack of consensus in the competency definition has been considered problematic. For instance, Jubb and Robotham (1997), notable critics of the approach, label the competency discourse as 'confusing and confused' and declare the approach a 'myth' (p. 175) whose validity has not been adequately proven. As mentioned earlier, the definition difference is a result of the multi-disciplinary nature of the discipline. Competency has originated from the disciplines of psychology, management / human resource, education and political disciplines (Burgoyne, 1993; Hoffmann, 1999). Each discipline with different interests that affects its orientation towards macro/micro, theoretical/practical and technical/practical dimensions (Burgoyne, 1993). Psychologists concern with individual traits for effective performance (e.g. Rhee, 2008; Boyatzis, 1982). Human resources pursue it as a tool for organizational strategic planning (e.g. Clardy, 2008; Rees \& Doran, 2001). Whilst some educationists perceive it as a political move to vocationalize education (e.g. Macfarlane and Lomas, 1994). Given these diversions, competency definition provided by a particular author is therefore oriented towards the purpose of his / her discipline. This phenomenon can be seen in the competency definitions forwarded for instance, by Boyatzis (psychology), Woodruffe (human resource) and Hager and Beckett (education).

Competency models have been said incompatible with our fast-changing world. Caldwell (2003) argues that identification of relevant competencies is 'impossible' and not 'useful' in this volatile environment. The use of functional analysis technique, common in many competency studies, is retrospective rather than prospective. Antonacopoulou and FitzGerald's remarked that "instead of growing dynamic, flexible and adaptable managers, capable of facing the challenges of tomorrow, the risk seems to be that the competency framework is, in an evolving society, cultivating dinosaurs struggling to develop the skills of the past" (1996: 34). Macfarlane and Lomas (1994) declared the MCI competence approach as characterized by conformity, control, being present and inward-looking which they argued is in total disharmony with the concept of learning organization that requires managers to empower, reflect, debate and concentrate on future needs.

And the lastly, the idea of the generic competency framework has been said to ignore the importance of work context in influencing managerial behaviours (McKenna, 2004; Burgoyne, 1989). The generic models wrongly assume that managerial works are standardized and that the required competencies are similar across organizations and countries. A manager considered 'competent' in one organization, industry or in a particular country will not necessarily perform well in other contexts. The importance of context to managerial effectiveness has been repeatedly proven in the literature (e.g. Hofstede, 2001; Erondu, 2002). Even within the same organization, interpretation and application of certain competencies varies amongst managers (Antonacopoulou \& FitzGerald, 1996; Hayes et al., 2000).

\section{Propositions}

The following present two suggestions which researchers may consider when researching competency. These suggestions aim to downplay the above-mentioned criticisms towards the subject.

\subsection{Proposition 1 - Epistemological Consideration}

Wrong epistemology has been pointed out as the root cause for the widespread criticisms (Burgoyne, 1989; Garavan \& McGuire, 2001; Sandberg, 2000). Being originated from psychology, competency shares many of the discipline's positivistic tradition in its assumptions of human behaviours. Rather than capturing 'actual' competencies from employees' perspectives, positivism was argued results researchers' own preconceived ideas of an 'ideal' framework even before they commence fieldwork (Sandberg, 2000). Sandberg further argues that employing positivism in competency studies was wrong because it "invoke(s) a dualistic ontology, assuming that person and world are distinct entities, and an objectivistic epistemology, assuming the existence of an objective reality independent of and beyond the human mind" (p. 11). The positivistic approach is obvious with the use of functional analysis method and measurement of managerial performance. The functional analysis method breaks down management functions into a series of disintegrated tasks followed by their required standards. This practice violates the holism/reductionism principle (Hager \& Beckett, 1995) and results a series of 'can do' lists involved in managerial work. The problem with this approach is even if managers were able to perform and achieve the standards listed, they would not be necessarily considered competent managers (ibid.). 
With regard to measurement of managerial performance, rationalistic assumption that performance is observable and measurable tends to emphasize tangible outcomes as opposed to the learning process which is soft and self-perceptual. This perspective clearly undervalues concepts such as self-reflection which is significant to one's learning. The grave differences in the ontology, epistemology and methodologies between the existing competency studies and the reality of (i.e. leadership) practice was also noted by Carroll et al. (2008) as shown in Table 2.

Table 2. The competency / practice distinction (Carroll et al., 2008, p. 366)

\begin{tabular}{lll}
\hline \multicolumn{1}{c}{ Competency } & \multicolumn{1}{c}{ Practice } \\
\hline - Rooted in objectivism & $\bullet$ & Explicit constructionist \\
- Individual level of analysis & $\bullet$ & Inherently relational and collective \\
- Quantifiable and measurable & Discourse, narrative and rhetoric \\
- Pnanchored in relationship and context & Privileges reason & - Situated and socially defined \\
- Assumes intellect predominantly & - Incorporates embodiment and emotion \\
\hline
\end{tabular}

These arguments suggest that researching and developing managerial competency frameworks based on positivistic lenses are inappropriate as it oversimplifies the complex nature of managerial work, which in reality involves a lot of unobservable, immeasurable and subjective activities. The use of positivism in competency studies at best results in erroneous descriptions and prescriptions of managerial jobs. Therefore, an alternative epistemology, one which is in better harmony with the qualitative nature of managerial work may be required to produce more valid competency findings.

Interpretivism has been suggested as the more appropriate epistemology to study competencies (Garavan \& McGuire, 2001). Interpretivism regards social reality as a product of its inhabitants hence the study of social phenomena requires an understanding of the social world that people have constructed and which they produce through their continuing activities (Blaikie, 2007, p. 124). Phenomenology, one of interpretivism variants, ensures that the competency framework is contextually-specific and appropriately values the learning journey that individuals experience. Phenomenology is able to solve many of the flaws in competency models because it treats a worker and his/her work as inextricably related (Sandberg, 2000). It also allows rooms for competency adjustment depending on contextual factors and gives each organization its competitive advantage by cultivating unique competencies on its managers. This view also concurs with the suggestion by Bolden and Gosling (2006) who argue that research on (leadership) competency frameworks should explore the symbolic and narrative nature of collective sense making in organizations, move from the individualistic notions of leadership to more inclusive and relational perspectives, and emphasize on the processes by which competency frameworks can contribute towards enhanced organizational performance to better understand its application and usefulness. Anthropology, narrative and storytelling (McKenna, 2004) and managerial portfolio (Burgoyne, 1989) are some of the recommended methods in competency research to capture the qualitative aspects of managerial work and competence. Interpretivism allows researchers to recognize that various interpretations exist with regard to managerial competencies, and the significance of contexts in determining the applicability of a specific competency.

\subsection{Proposition 2 - Ideological Consideration}

Competency frameworks can do better in serving beyond its traditional stakeholder. Given the increasingly complex roles and higher accountability of business where their contributions to societal and environmental health are as important as economic wealth, competency frameworks must be developed by considering both utilitarian and humanist ideologies. As discussed earlier, the definition of 'competent' and 'effective performance' have been mostly viewed from a narrow utilitarian lense dictated by organization profit maximization agenda. There is an apparent lack of attention on ethical and societal considerations to how 'effective job performance' is achieved. Changes in business environments have constantly evolved and redefined managerial roles from 'organization man' (Whyte, 1956), 'individualized cooperation' (Bartlett \& Goshal, 1997) to 'social entrepreneurs' (London \& Marfopoulos, 2010). Global problems have increased demands for businesses and their managers to think about the consequences of their actions before making any decisions. Peter Drucker (1985) has emphasized before that managers are simultaneously responsible to organizational economic performance, their employees' well-being, and the interests of society. He argued that "free enterprise cannot be 
justified as being good for business. It can be justified only as being good for society" (p. 41) and that managers are 'leadership group of the modern society' (p. 325). The economic and social responsibilities of businesses and managers are louder especially in recent years have created an increased interests from the academe (Ghoshal, 2005; Khurana, 2007) and other bodies like the Association to Advance Collegiate Schools of Business (AACSB), Global Reporting Initiative (GRI) and Principle for Responsible Management Education (PRME). Therefore, to ensure that managers these roles are performed well, holistic managerial competencies framework which consist of to cover the functional, personal and ethical sides of their responsibilities are necessary. Furthermore, multiple ideologies can work well with the multi-disciplined backgrounds of the competency approach as mentioned earlier.

\section{Conclusion}

This article has discussed the theoretical foundations underpinning the competency approach. It looks at the origins of the approach with specific focus on the US and UK competency/e movements and discusses how these backgrounds have contributed to the different understanding and usage of the competency approach. The article also highlights the multi-disciplinary nature of the competency approach and shows how this has attracted mixed reactions from scholars. The author then discussed the main criticisms towards the approach and suggested that these may have been caused by the prevalent positivist epistemology which guides many competency researches. With this understanding, the article then forwards two propositions which call for epistemological and ideological considerations in future studies on the subject.

This article contributes to the growing efforts in the field of competency which embrace research epistemological turns and recognize the need for holistic managerial frameworks. Being competent involves both competencies and competence. It is a journey to a destination. Managerial learning does not only occur formally but much is contributed through informal process. Corporations and their managers are accountable to multiple stakeholders. Hence, managerial competency frameworks should be designed to meet both economic and humanist interests. Capturing these tenets is crucial for the frameworks to be a truly useful and relevant tool to guide organizations' human resource initiatives in the increasingly-complex business world. While the contribution of this article may not be totally novel and the wind of change can already be seen elsewhere (eg. Quoquab et al., 2014), this article provides a thought-pondering issue for countries where positivism still remain the preferred epistemology and managerial accountability rarely goes beyond their economic responsibilities.

\section{References}

Ab Rahman, A., Muhamad Hanafi, N., Ibrahim Mukhtar, M., \& Ahmad, J. (2014). Assessment Practices for Competency based Education and Training in Vocational College, Malaysia. Procedia - Social and Behavioral Sciences, 112, 1070-1076. http://dx.doi.org/10.1016/j.sbspro.2014.01.1271

Albanese, R. (1990). Competency-Based Management Education: Three Operative and Normative Issues. Journal of Management Education, 14(1), 16-28. http://dx.doi.org/10.1177/105256298901400102

Antonacopoulou, E., \& FitzGerald, L. (1996). Reframing Competency in Management Development. Human Resource Management Journal, 6(1), 27-48. http://dx.doi.org/10.1111/j.1748-8583.1996.tb00395.x

Azmi, I. A. G. (2010). Competency-based Human Resource Practices in Malaysian Public Sector Organizations. African Journal of Business Management, 4(2), 235-241.

Bartlett, C. A., \& Ghoshal, S. (1997). The Myth of the Generic Manager: New Personal Competencies for New Management Roles. California Management Review, 40(1), 92-116.

Besler, S., \& Sezerel, H. (2011). Core Competences in Non- Governmental Organizations: A Case Study. Procedia - Social and Behavioral Sciences, 24, 1257-1273. http://dx.doi.org/10.1016/j.sbspro.2011.09.106.

Blaikie, N. (2007). Approaches to Social Inquiry. Cambridge: Polity Press.

Bolden, R., \& Gosling, J. (2006). Leadership Competencies: Time to Change the Tune? Leadership, 2, 147-163.

Boyatzis, R. E. (1982). The Competent Manager: A Model for Effective Performance. New York: John Wiley \& Sons.

Boyatzis, R. E., Stubbs, E., \& Taylor, S. N. (2002). Learning Cognitive and Emotional Intelligence Competencies Through Graduate Management Education. Academy of Management Learning and Education, 1(2), 150-162. http://dx.doi.org/10.5465/AMLE.2002.8509345

Brown, R. B. (1993). Meta-competence: A Recipe for Reframing the Competence Debate. Personnel Review, 22(6), 25-36. http://dx.doi.org/10.1108/EUM0000000000814 
Burgoyne, J. (1989). Creating the Managerial Portfolio: Building on Competency Approaches to Management Development. Management Education and Development, 20(1), 56-61.

Caldwell, R. (2008). HR Business Partner Competency Models: Re-Contextualising Effectiveness. Human Resource Management Journal, 18, 275-294.

Carroll, B., Levy, L., \& Richmond, D. (2008). Leadership as Practice: Challenging The Competency Paradigm. Leadership, 4(4), 363-379. http://dx.doi.org/10.1177/1742715008095186

Cheetham, G., \& Chivers, G. (1998). The Reflective (and Competent) Practitioner: A Model of Professional Competence Which Seeks to Harmonise the Reflective Practitioner and Competence-Based Approaches. Journal of European Industrial Training, 22(7), 267-276. http://dx.doi.org/10.1108/03090599810230678

Clardy, A. (2008). The Strategic Role of Human Resource Development in Managing Core Competencies. Human Resource Development International, 11(2), 183-197. http://dx.doi.org/10.1080/136788608019329 98

Constable, J., \& McCormick, R. (1987). The Making of British Managers. London: British Institute of Management.

Drucker, P. F. (1985). Management: Tasks, Responsibilities, Practices. New York: HarperCollins Publishers.

Erondu, E. A. (2002). The Concept and Application of Managerial Competence in Developed and Developing Economies: A Two Country Analysis. Journal of African Business, 3(2), 59. http://dx.doi.org/10.1300/ J156v03n02_04

Quoquab, F., Mohd Yassin, N., \& Abu Dardak, R. (2014). A qualitative inquiry of multi-brand loyalty. Asia Pacific Journal of Marketing and Logistics, 26(2), 250-271. htt://dx.doi.org/10.1108/APJML-02-2013-0023

Finch-Lees, T., Mabey, C., \& Liefooghe, A. (2005). In the Name of Capability': A Critical Discursive Evaluation of Competency-based Management Development. Human Relations, 58(9), 1185-1222. http://dx.doi.org/10.1177/0018726705059121

Garavan, T. N., \& McGuire, D. (2001). Competencies and Workplace Learning: Some Reflections on the Rhetoric and the Reality. Journal of Workplace Learning, 13(3/4), 144-163. http://dx.doi.org/10.1108/13665 620110391097

Ghoshal, S. (2005). Bad Management Theories are Destroying Good Management Practices. Academy of Management Learning and Education, 4(1), 75-91. http://dx.doi.org/10.5465/AMLE.2005.16132558

Gonczi, A. (1994). Competency Based Assessment in the Professions in Australia. Assessment in Education: Principles, Policy and Practice, 1(1), 27-44. http://dx.doi.org/10.1080/0969594940010103

Grzeda, M. M. (2005). In Competence We Trust? Addressing Conceptual Ambiguity. Journal of Management Development, 24(6), 530-545. http://dx.doi.org/10.1108/02621710510600982

Hager, P., \& Beckett, D. (1995). Philosophical Underpinnings of the Integrated Conception of Competence. Educational Philosophy and Theory, 27(1), 1-24. http://dx.doi.org/10.1111/j.1469-5812.1995.tb00209.x

Handy, C. B., Gordon, C., Gow, I., \& Randlesome, C. (1987). Making Managers. London: Pitman Publishing.

Hayes, J., Rose-Quirie, A., \& Allinson, C. W. (2000). Senior Managers' Perceptions of the Competencies They Require for Effective Performance: Implications for Training and Development. Personnel Review, 29(1), 92-105. http://dx.doi.org/10.1108/00483480010295835

Hoffmann, T. (1999). The Meanings of Competency. Journal of European Industrial Training, 23(6), 275-285. http://dx.doi.org/10.1108/03090599910284650

Hofstede, G. (2001). Culture's Consequences: Comparing Values, Behaviours, Institutions and Organizations Across Nations. London: Sage.

Hondeghem, A., \& Vandermeulen, F. (2000). Competency management in the Flemish and Dutch Civil Service. International Journal of Public Sector Management, 13(4), 342-353. http://dx.doi.org/10.1108/095135 50010350355

Horton, S. (2000a). Competency Management in the British Civil Service. International Journal of Public Sector Management, 13(4), 354-368. http://dx.doi.org/10.1108/09513550010350508

Horton, S. (2000b). Introduction - The Competency Movement: Its Origins and Impact on the Public Sector. International Journal of Public Sector Management, 13(4), 306-318. http://dx.doi.org/10.1108/095135500 
10350283

Hyland, T. (1994). Competence, Education and NVQs. London: Cassell.

Ismail, H. N., Al-Zoubi, S. M., Rahman, M. B. A., \& Al-Shabatat, A. M. (2009). Competency Based Teacher Education (CBTE): A Training Module for Improving Knowledge Competencies for Resource Room Teachers in Jordan. European Journal of Social Sciences, 10(2), 166-178.

Jamil, R. (2011). Stakeholders' perceptions of MBA provision by public universities in Malaysia (Unpublished $\mathrm{PhD}$ thesis). University of Manchester, Manchester, United Kingdom.

Jubb, R., \& Robotham, D. (1997). Competences in Management Development: Challenging the Myths. Journal of European Industrial Training, 21(5), 171-175. http://dx.doi.org/10.1108/03090599710171422

Khurana, R. (2007). From Higher Aims to Hired Hands: The Social Transformation of American Business Schools and the Unfulfilled Promise of Management as a Profession. New Jersey: Princeton University Press.

Lee, M., Letiche, H., \& Crawshaw, R. (Eds.). (1996). Management Education in the New Europe. London: International Thomson Business Press.

Liu, M., Kunaiktikul, W., Senaratana, W., Tonmukayakul, O., \& Eriksen, L. (2007). Development of competency inventory for registered nurses in the People's Republic of China: Scale development. International Journal of Nursing Studies, 44(5), 805-813. http://dx.doi.org/10.1016/j.jpurstu.2006.01.010.

London, M., \& Marfopoulos, R. G. (2010). Social entrepreneurship. New York: Routledge.

Macfarlane, B., \& Lomas, L. (1994). Competence-based Management Education and the Needs of the Learning Organization. Education + Training, 36(1), 29-32. http://dx.doi.org/10.1108/00400919410052267

McClelland, D. C. (1973). Testing for Competence Rather Than for 'Intelligence'. American Psychologist, 28, $1-14$.

McKenna, S. (2004). Predispositions and Context in the Development of Managerial Skills. Journal of Management Development, 23(7), 664-677. http://dx.doi.org/10.1108/02621710410546669

Mumford, A., \& Gold, A. (2004). Management Development: Strategies for Action. London: Chartered Institute of Personnel and Development.

Parker, B., \& Walters, S. (2008). Competency based training and national qualifications frameworks: Insights from South Africa. Asia Pacific Education Review, 9(1), 70-79. http://dx.doi.org/10.1007/bf03025827

Prahalad, C. K., \& Hamel, G. (1990). The Core Competence of the Corporation. Harvard Business Review, 68(3), 79-91.

Rees, C. J., \& Doran, E. (2001). Employee Selection in a TQM Context: Taking a Hard Look at a Soft Issue. Total Quality Management, 12(8), 855-860. http://dx.doi.org/10.1080/09544120100000007

Rees, C., Jamil, R., \& Rowlands, K. (2015). Blame the parents! Attitudes towards business ethics with reference to MBA programs in Malaysia. Industrial and Commercial Training, 47(5), 221-227. http://dx.doi.org/10. 1108/ICT-03-2015-0021

Rhee, K. S. (2008). The Beat and Rhythm of Competency Development Over Two Years. Journal of Management Development, 27(1), 146-160. http://dx.doi.org/10.1108/02621710810840811

Robotham, D., \& Jubb, R. (1996). Competences: Measuring the Unmeasurable. Management Development Review, 9(5), 25-29.

Samra-Fredericks, D. (2003). Strategizing as Lived Experience and Strategists' Everyday Efforts to Shape Strategic Direction. Journal of Management Studies, 40, 141-174. http://dx.doi.org/10.1111/1467-6486.t01$1-00007$

Sandberg, J. (2000). Understanding Human Competence at Work: An Interpretative Approach. Academy of Management Journal, 43(1), 9-25. http://dx.doi.org/10.2307/1556383

Spencer, L. M., \& Spencer, S. M. (1993). Competence at Work: Models for Superior Performance. New York: John Wiley and Sons.

Su-Chin, H., Jui-Shin, L., \& Hung-Chun, L. (2012) Analysis on Literature Review of Competency. International Review of Business and Economics, 2, 25-50.

Thorpe, R., \& Easterby-Smith, M. P. V. (1997). Research traditions in management learning. In J. Burgoyne, \& 
M. Reynolds (Eds.), Management Learning: Integrating Perspectives in Theory and Practice (pp. 38-53). London: Sage.

Viitala, R. (2005). Perceived Development Needs of Managers Compared to an Integrated Management Competency Model. Journal of Workplace Learning, 17(7), 436-451. http://dx.doi.org/10.1108/1366562 0510620025

Whyte, W. H. (1956). The Organization Man. New York: Simon and Schuster.

Woodruffe, C. (1993). Assessment Centres: Identifying and Developing Competence. London: Institute of Personnel Management.

Young, M. (2002). Clarifying Competency and Competence. (The Henley Working Paper Series). Oxon: Henley Management College.

\section{Note}

Note 1. McClelland used the word 'competency' in his 1973's seminal paper but did not formally define it.

\section{Copyrights}

Copyright for this article is retained by the author (s), with first publication rights granted to the journal.

This is an open-access article distributed under the terms and conditions of the Creative Commons Attribution license (http://creativecommons.org/licenses/by/3.0/). 